\title{
HOW SHOULD COMPANIES THAT RECEIVE R\&D\&I FUNDS COMMUNICATE? LEGAL REQUIREMENTS IN SPAIN
}

\author{
¿Cómo deben comunicar las empresas receptoras de \\ ayudas de l+D+i? Requisitos legales en España
}

María J. Vilaplana-Aparicio, Marta Martín-Llaguno and Mar Iglesias-García

Nota: Este artículo se puede leer en español en:

http://www.elprofesionaldelainformacion.com/contenidos/2018/may/16_esp.pdf

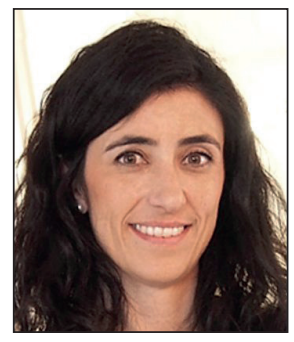

María J. Vilaplana-Aparicio, with a degree in Advertising and Public Relations, is a professor at the Department of Communication and Social Psychology (Departamento de Comunicación y Psicología Social) at the Universidad de Alicante. She combines teaching the Advertising and Public Relations degree with innovation consulting, and conducts courses and workshops related to R\&D\&I.

https://orcid.org/0000-0002-6373-8454

maria.vilaplana@ua.es

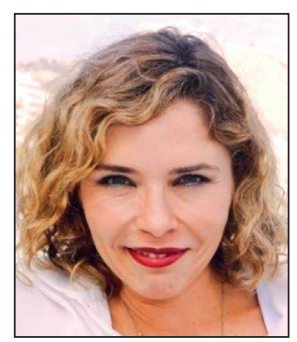

Marta Martín-Llaguno, professor of Communication, has published around fifty articles in indexed journals and has participated in more than twenty competitive projects (European, national and regional). She has been a visiting professor at the Universidad de Piura (Perú) and at the Universidad Católica de Buenos Aires, and has been a visiting researcher at the IESE Business School and the City University of New York (USA). She is a member of the jury of the Independent Advertising Self-Regulatory Organisation (SRO) in Spain (Jurado de Autocontrol de la Publicidad). Currently she is on special services secondment.

https://orcid.org/0000-0003-2252-5505

marta.martin@ua.es

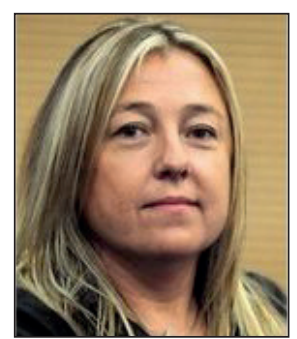

Mar Iglesias-García is a journalist and professor in the Department of Communication and Social Psychology (Departamento de Comunicación y Psicología Social) at the Universidad de Alicante. She teaches the Advertising and Public Relations degree and the Tourism degree. She collaborates in the research project Creation and interactive content in audiovisual information communication: audiences, design, systems and formats (Creación y contenido interactivo en la comunicación de información audiovisual: audiencias, diseño, sistemas y formatos), funded by the Ministry of Economy, Industry and Competitiveness of Spain (Ministerio de Economía y Competitividad). She is vice president of the Valencian Media Corporation (Corporació Valenciana de Mitjans de Comunicació, CVMC) and director of RàdioUA.

https://orcid.org/0000-0001-7926-5746

mar.iglesias@ua.es

Universidad de Alicante Campus Sant Vicent del Raspeig. Ap. 99. 03080 Alicante, Spain

\begin{abstract}
Companies receiving funds for their research, development and technological innovation (R\&D\&I) activities must comply with communication obligations so that citizens are informed of the projects that are financed using public funds. The information requirements are defined both in the European and Spanish legal framework. The objective of this paper is to compile this legislation and analyse the communication and data sharing obligations that are required for these funding recipients. The results indicate that the communication obligations of the subsidised projects are very general. It is compulsory to standardise the terms used, the actions requested and the content of these, and to promote data sharing in companies, all through a repository that brings together the R\&D\&I projects funded.
\end{abstract}

\section{Keywords}

Dissemination; Communication; Advertising; Data sharing; Innovation; R\&D\&I. 


\section{Resumen}

Las empresas receptoras de ayudas para sus actividades de investigación, desarrollo e innovación tecnológica (I+D+i) deben cumplir con unas obligaciones de comunicación para que la población esté informada de los proyectos que se financian con fondos públicos. Esos requisitos de información están definidos en el marco legal europeo y español. El objetivo de este trabajo es recopilar esta legislación y analizar las obligaciones de comunicación y data sharing que se exigen a los receptores de fondos. Los resultados indican que las obligaciones de comunicación de los proyectos subvencionados son muy generales. Es necesario homogeneizar los términos utilizados, las acciones solicitadas y el contenido de las mismas, y promover el data sharing en las empresas mediante un repositorio que aglutine los proyectos de I+D+i financiados.

\section{Palabras clave}

Difusión; Comunicación; Publicidad; Data sharing; Compartir datos; Innovación; I+D+i.

Vilaplana-Aparicio, María J.; Martín-Llaguno, Marta; Iglesias-García, Mar (2018). "How should companies that receive R\&D\&I funds communicate? Legal requirements in Spain". El profesional de la información, v. 27, n. 3, pp. 633-640.

https://doi.org/10.3145/epi.2018.may.16

\section{Introduction}

For its contribution to the progress and well-being of society, innovation (and its motivation) is the subject of public policies in the European Union (EU), and in the Spanish central and autonomous administrations, which focus on encouraging $\mathrm{R}+\mathrm{D}+\mathrm{l}$ in companies. For this purpose, a system of assistance has been organised that encourages companies to develop projects that would not be undertaken without public support (González; Jaumandreu; Pazó, 2005).

In 2017, Spain allocated 6,029 million euros to civil R\&D (Minhap, 2017), with the goal of achieving an investment equivalent to $2 \%$ of GDP by 2020 (Mineco, 2013). These funds are distributed through various organisations such as the Spanish Ministry of Economy, Industry and Competitiveness (Ministerio de Economía y Competitividad, Mineco) or the Centre for Industrial Technological Development (Centro para el Desarrollo Tecnológico Industrial, CDTI), and mainly materialise in the form of direct grants (especially soft loans and non-refundable grants) and indirect aid (tax incentives and bonuses).

Although the promotion of R\&D in companies is key, it is not the only aspect that concerns the agencies managing public funds. For some years, the EU and Spain have demonstrated the need to increase communication activities so that citizens are informed of the projects and companies that are supported, in order to achieve transparency.

a) For the EU and its member states, transparency is a fundamental issue on which they have focused their attention. As a result, the Law on transparency, access to public information and good governance has been enacted (España, 2013c), which aims to guarantee Spanish citizens access to public information.

Some initiatives have also been promoted, such as the Transparency Portal of the Government of Spain (Portal de transparencia) or the National portal on grants and subsidies (Sistema nacional de publicidad de subvenciones, SNPS) that collects information on the grants awarded, specifying the funding agency, the name of the program, the beneficiary and the amount granted. b) The need to achieve greater transparency is linked to the interest in ensuring that public resources are used efficiently. Consequently, the EU managing bodies strive because the entities receiving aid make their data partially or wholly available to the rest of researchers. This field of study is known as data sharing and

"it consists of sharing the final research data among scientists, with the aim of maximising efforts and resources" (Torres-Salinas; Robinson-García; Cabezas-Clavijo, 2012).

The Law on science, technology and innovation in Spain includes both aspects and shows that

"dissemination and transfer are essential elements of modern culture".

In addition, it points out that there is a

"commitment to the universal dissemination of knowledge, through positioning in favour of policies of open access to scientific information" (España, 2011).

With its entry into force, for the first time it is obligatory to publish research results in open access and it is necessary to promote the development of public repositories. But these demands focus on the public domain of the Spanish system of science, technology and innovation (Sistema español de ciencia, tecnología e innovación) and their research staff, and makes companies exempt from these requirements.

\section{Transparency and communication of R\&D projects}

There are studies that address transparency in Spanish public university research projects (Pacios; Vianello-Osti; Rodríguez-Bravo, 2016), transparency of information published by the central administration (Beltrán-Orenes; Martínez-Pastor, 2016) or by local administrations (Moreno-Sardà; Molina-Rodríguez-Navas; Simelio-Solà, 2017).

However, there are very few studies addressing the obligations of communication and transparency in private companies. This field of study is still to be explored if we take into account that there are cases of private companies receiving public funds, and which therefore should be obliged to carry 
out communication activities. Despite the scarcity of scientific production on this topic, a prominent study analysing the correct implementation of the Transparency law in large Spanish companies (Cruz-Rubio, 2017) concludes that the information published by companies is incomplete, dispersed, and differs from one company to another in quality and specialty. Additionally, the contributions of Beltrán-Orenes and Martínez-Pastor (2017) conclude that, after analysing the information that should appear in the Portal of Transparency of Spain and the obligated subjects, private entities, in spite of being obliged to comply with the principles of transparency, do not publish the information stated by the Law.

\subsection{Access to information on supported projects}

The benefits of sharing data and the aim to promote it have led the $O E C D$ to develop principles and guidelines for access to research data on public funding (OECD, 2007). The fast development of information and communication technologies have opened new possibilities for the scientific community, through the creation of open access repositories.

The European Commission has developed policies and measures on open access since 2006, to ensure the widest possible dissemination of research results financed with public funds and optimise their impact. For this reason, in the European framework program that finances R\&D\&I projects (Horizon 2020), open access is a general principle, and one of the measures that has been adopted is to consider eligible the costs of publication to this system.

A measure to share information has been the creation of databases that gather scientific works. Open Access Infrastructure for Research in Europe, known as OpenAIRE, is one of the most outstanding initiatives in Europe. It is a project funded by the $E C$ that brings together more than 21 million publications from nearly 2,400 data sources.

Another database is Recolecta, a project carried out in Spain between the Spanish Foundation for Science and Technology (Fundación para la Ciencia y la Tecnología, Fecyt) and the Spanish Academic Libraries Network (Red de Bibliotecas Universitarias de España, Rebiun). It is a platform that links all scientific repositories and that seeks to give greater visibility to the results of Spanish research. Other initiatives are Teseo, which brings together doctoral theses conducted in Spanish universities, promoted by the Ministry of Education (Ministerio de Educación).

However, these projects focus primarily on the university research communities and research centres. There are no initiatives focused on research developed by private companies, which makes this an interesting point if we bear in mind that in the future everything points out that

"the projects that request funding must submit a research data management plan so that they can be shared" (Hernández-Pérez; García-Moreno, 2013).

If we consider the importance that the EU gives to communication, transparency and access to the data of the subsidised research, it is of interest to explore this matter to know what measures related to the communication and the exchange of data are being requested from the companies in the regulatory framework. This could be a starting point to define the requirements for communication and data sharing included in the future legal code.

\section{Objectives and method}

The objective of this research is to analyse the information, communication and data sharing requirements that must be fulfilled by companies that receive R\&D\&l funds in Spain. Specifically, it aims to compile and review the standardisation that (directly and indirectly) regulates R\&D grants aimed at Spanish entities, to analyse, classify and describe the communication obligations that must be met.

To reach these objectives, all legal texts in force have been identified. In the case of direct aid, the websites of the General Directorate of Community Funds within the Ministry of Finance and Public Function (Dirección General de Fondos Comunitarios del Ministerio de Hacienda y Función Pública), the Secretary of State of Research, Development and Innovation (Secretaría de Estado de Investigación, Desarrollo e Innovación, Seidi) and the Centre for the Development of Industrial Technology (Centro para el Desarrollo Tecnológico Industrial, CDTI) have been analysed. State and European regulations have been sought and compiled, as part of the grants are European funds.

On the website of the aforementioned Secretary of State for Research, Development and Innovation, the texts that regulate indirect aid have been identified, and later the texts of the Official State Gazette (Boletín Oficial del Estado, BOE) have been extracted.

Once the standards have been compiled, the texts have been analysed to identify the requirements and statements exposed in them, related to communication, transparency and data sharing (Table 1).

Table 1. Variables analysed in legal texts

\begin{tabular}{|l|l|}
\hline \multicolumn{1}{|c|}{ Variable to analyse } & Revised content \\
\hline Title of the article & Name of the article that introduces the communication measures \\
\hline $\begin{array}{l}\text { Dissemination activities to be carried out and content of the } \\
\text { actions }\end{array}$ & Activities that are considered and content specifications \\
\hline Intensity of the dissemination & Variation of dissemination intensity according to the characteristics of the project \\
\hline Responsibilities & People responsible for carrying out communication activities \\
\hline Non-compliance & Consequences of non-compliance with dissemination actions \\
\hline Data sharing & Activities related to data sharing \\
\hline
\end{tabular}


We have analysed how these requirements are introduced in the code, what should be communicated, whether there is discrimination according to the characteristics of the project, who is responsible for carrying out the dissemination actions, what happens if the required measures are not implemented and whether activities related to data sharing are taken into account.

\section{The EU and Spain agree on the need to communicate more}

\section{Results}

\subsection{Compilation of the regulatory framework}

There are ten regulatory documents that control direct R\&D\&I grants in Spain, as shown in Table 2. These contain explicit mention of communication and information requirements or, failing that, a reference to compliance with the obligations on the part of the beneficiaries: three are of European scope and seven of state scope.

Indirect aid is regulated by three state-level documents (table 2) and also by the Framework on state aid for research and development and innovation (European Commission, 2014), which is common to direct and indirect aid.

\subsection{Communication requirements}

The results of the analysis of the variables being studied (Ta- ble 1) are presented below following the classification in Table 2, based on two large blocks: direct aid and indirect aid.

\subsubsection{Direct aid}

\section{Title of the article}

The terms advertising, information and communication are used interchangeably in legal texts. While the European reference provisions use the terms "information and communication" (European Union, 2013; European Union, 2014), the Spanish state texts speak of "advertising" the subsidies (España, 2003a; España, 2006; España, 2013a; España, 2013b; España, 2014b; España, 2015), and both mention transparency (España, 2013c; European Commission, 2014). In all cases they refer to the effort that beneficiaries must make to communicate the project, or its results, to the public.

\section{Dissemination activities and their content}

The dissemination activities and the content of the actions are contemplated in the different texts (table 3). In Europe, Annex XII of Regulation n. 1303 (EU, 2013) indicates that the beneficiary must assume the following obligations:

- Recognise support by inserting the reference, emblems, and logos.

- Create a description on the website that is proportional to the support received and that includes the objectives and results.

- Place a poster with the project information.

- Inform all parties of the financing.

Table 2. Number of current legal texts analysed

\section{Description}

\begin{tabular}{|c|c|c|}
\hline & & Description \\
\hline \multirow[b]{2}{*}{$\begin{array}{l}\text { Direct } \\
\text { aid }\end{array}$} & $\begin{array}{l}\text { European } \\
\text { regulations }\end{array}$ & $\begin{array}{l}\text { - Regulation (EU) n. 1303/2013 of the European Parliament and of the Council, of } 17 \text { December laying down common } \\
\text { provisions for the European Regional Development Fund, the European Social Fund, the Cohesion Fund, the European } \\
\text { Agricultural Fund for Rural Development, and to the European Maritime and Fisheries Fund, and laying down general } \\
\text { provisions concerning the European Regional Development Fund, the European Social Fund, the Cohesion Fund and the } \\
\text { European Maritime and Fisheries Fund. } \\
\text { - Framework on state aid for research and development and innovation (2014/C 198/01). } \\
\text { - Implementing Regulation (EU) n. } 821 / 2014 \text {, of } 28 \text { July, by which the provisions for the application of Regulation (EU) n. } \\
1303 / 2013 \text { of the European Parliament and of the Council as regards the specific modalities for the transfer and manage- } \\
\text { ment of program contributions, the presentation of information on financial instruments, the technical characteristics } \\
\text { of information and communication measures of operations, and the system for recording and storing data. }\end{array}$ \\
\hline & $\begin{array}{l}\text { State } \\
\text { regulations }\end{array}$ & $\begin{array}{l}\text { - Law 38/2003, of } 17 \text { November, General law of subsidies. } \\
\text { - Royal decree 887/2006, of July 21, which approves the Regulation of Law 38/2003, of November 17, General law of } \\
\text { subsidies } \\
\text { - Law } 19 / 2013 \text {, of } 9 \text { December, on transparency, access to public information and good governance. } \\
\text { - Order ECC/1780/2013, of } 30 \text { September, which approves the regulatory bases for the granting of public aid of the State } \\
\text { program for research, development and innovation oriented to the challenges of the society within the framework of the } \\
\text { State plan of scientific and technical research and innovation } 2013-2016 \text {. } \\
\text { - Order ECC/1402/2013, of } 22 \text { July, which approves the regulatory bases for the granting of aid within the framework of } \\
\text { the State program for the promotion of talent and its employability of the State plan for scientific and technical research and } \\
\text { innovation 2013-2016. } \\
\text { - Law } 15 / 2014, \text { of } 16 \text { September, on the rationalisation of the Public Sector and other administrative reform measures } \\
\text { - Order ECC/1133/2015, of } 2 \text { July, approving the regulatory bases for the granting of public aid from the State business } \\
\text { leadership program in } R+D+l, \text { within the framework of the State plan for scientific research and technical and innovation } \\
\text { 2013-2016. }\end{array}$ \\
\hline \multirow[b]{2}{*}{$\begin{array}{l}\text { Indirect } \\
\text { aid }\end{array}$} & $\begin{array}{l}\text { European } \\
\text { regulations }\end{array}$ & - Framework on state aid for research and development and innovation (2014/C 198/01). \\
\hline & $\begin{array}{l}\text { State } \\
\text { regulations }\end{array}$ & $\begin{array}{l}\text { - RD 1432/2003, of November } 21 \text {, which regulates the broadcast by the Ministry of Science and Technology (Ministerio } \\
\text { de Ciencia y Tecnología) of the resulting reports regarding compliance with scientific and technological requirements, } \\
\text { for the purposes of the application and interpretation of tax deductions for research and development activities and } \\
\text { technological innovation } \\
\text { - Law } 27 / 2014 \text {, of November } 27 \text {, on Corporation tax } \\
\text { - RD } 475 / 2014 \text {, of June } 13 \text {, on bonuses in the Social Security contribution of the research staff. }\end{array}$ \\
\hline
\end{tabular}


- In infrastructure or construction works with aid of more than $€ 500,000$, a temporary poster must be displayed during execution with the project information.

In addition, in Regulation n. 821 (EU, 2014), annex II indicates the technical characteristics for the exhibition of the Union logo and the reference to the fund or the funds that support the operation.

The European Framework on state grants for research, development and innovation, does not include an explicit reference to information and communication, but defines that

"Member States, the Commission, economic operators and the public should have easy access to all relevant acts and appropriate information on the aid granted" (EC, 2014a).

It also indicates that in operations where individual aid is greater than $€ 500,000$ it will be obligatory to publish the following:

- identity of individual beneficiaries; form and amount of aid granted to each beneficiary;

- date of the concession; type of beneficiary; beneficiary region; and

- primary economic sector in which it undertakes its activities.

In the Spanish regulatory framework, the General subsidies law refers to advertising:

"The beneficiaries must provide adequate publicity of the financing of programs, activities, investments or actions of any kind that are subject to subsidy, in the terms established by regulation" (España, 2003a).

Royal decree 887, by which the Regulation of the General law of subsidies is approved, talks about the "publicity" of the grant by the beneficiary. It specifies that the actions of

"dissemination must be adapted to the subsidised object, both in form and duration, and may include the inclusion of the institutional image of the grantor, as well as captions related to public financing" (España, 2006).
On the other hand, the General law on subsidies refers to the Transparency law to indicate that the beneficiaries must publicise the subsidies and aid and the information

"will be published in the corresponding electronic sites or websites and in a clear, structured and understandable way for those interested and, preferably, in reusable formats" (España, 2013c).

In the same way it is indicated that

"appropriate mechanisms will be established to facilitate the accessibility, interoperability, quality and reuse of published information, as well as their identification and location" (España, 2013c).

The Public sector rationalisation law also includes an explicit mention of the advertising of subsidies, specifying the same terms contemplated in the Transparency law and details that:

"The National Subsidies Database (Base de datos nacional de subvenciones) will serve as an electronic means for compliance with publicity obligations" (España, 2014b).

The beneficiaries must inform the citizens

As for texts that approve the regulatory bases for granting public aid directed to companies framed in the State Plan for scientific and technical research and innovation, they highlight the need, on the part of the beneficiary, to "publicise the aid", mentioning the origin of the aid in

"service and labour contracts, grants, publications, presentations, equipment, inventoried material and activities to disseminate funded research results" (España, 2013a; España, 2013b; España, 2015),

in addition to the website.
It should also be included in

"posters, commemorative plaques, printed materials, electronic or audio-visual media, or mentions made in the media".

In addition to the two previous regulations, we must consider the contributions made by the Transparency law (España, 2013c). It details the terms and conditions that must be fulfilled by, to mention a few, commercial companies in "whose share capital, the direct or indirect participation" of public administrations, autonomous agencies, state agencies, public business entities and public law entities, is greater than $50 \%$, and private entities that receive public aid exceeding $€ 100,000$ or when at least $40 \%$ of their annual income includes aid (and reaches at least $€ 5,000)$. Therefore, these entities must, among other things, publish

"subsidies and public subsidies granted detailing the amount, objective or purpose and beneficiaries".
Table 3. Summary of dissemination activities considered in European and state regulations

\begin{tabular}{|c|c|c|}
\hline & $\begin{array}{c}\text { European } \\
\text { regulation: } R e- \\
\text { gulation }(E U) n . \\
1303 / 2013\end{array}$ & $\begin{array}{c}\text { State regu- } \\
\text { lation: } R D \\
887 / 2006\end{array}$ \\
\hline Recognise the support of funds & Yes & Yes \\
\hline${ }^{*}$ Logo & Yes & Yes \\
\hline${ }^{*}$ Reference to the funds & Yes & No \\
\hline Description on the website & Yes & No \\
\hline Poster about the project & Yes & No \\
\hline Inform all parties & Yes & No \\
\hline Declaration in all documents & Yes & No \\
\hline Temporary poster in operations over $€ 500,000$ & Yes & No \\
\hline $\begin{array}{l}\text { Poster or permanent plaque once the operation } \\
\text { is finished }\end{array}$ & Yes & No \\
\hline $\begin{array}{l}\text { Instructions on the display of the logo and refer- } \\
\text { ence to funds }\end{array}$ & Yes & No \\
\hline $\begin{array}{l}\text { Technical characteristics of advertising plaques } \\
\text { and posters }\end{array}$ & Yes & No \\
\hline
\end{tabular}




\section{Intensity of dissemination}

In the European legal order, Regulation n. 1303 (EU, 2013) specifies that a description should be included on the website, which should be proportional to the support received. Therefore, there is a gradiation of the intensity that description should have, although it does not describe what proportion should be. In Spanish regulations, there is no specific mention of what kind of intensity dissemination activities should have, nor whether these should vary depending on aspects such as the amount received or the type of project supported.

\section{Who is responsible for communication?}

The responsibility for carrying out the communication falls on the beneficiaries of the projects, the managing authorities, as well as the institutions and the consultative bodies of the Union (EU, 2013).

The state texts point out that adopting the appropriate publicity measures on the grant obtained is one of the obligations of the beneficiaries (España, 2003a; España, 2006; España, 2013a; España, 2013b; España, 2014b; España, 2015). This is complemented by the contributions that must be made by the granting administrations, which must

"Refer to the National Grants Database (Base de datos nacional de subvenciones, BDNS) for information about calls and concession resolutions" (España, 2003a).

\section{Advertising, information and communi- cation are used interchangeably}

\section{Consequences of non-compliance}

European regulations do not specify the cases of non-compliance with communication obligations. On the other hand, in Spanish state regulations these assumptions are included in practically all legal texts (explicitly or generally). It is established that beneficiaries will have a term of 15 days to carry out the communication corrective activities (España, 2006; España, 2013a; España, 2013b; España, 2015), and, in the case of being impossible to perform them

"the granting body may establish alternative measures, as long as they allow the dissemination of the public financing received with the same scope as initially agreed." (España, 2006).

The General subsidies law (España, 2003) also mentions breach of advertising obligations by the beneficiary and points out that it will be cause for reimbursement.

\section{Data sharing}

The European and state legal texts analysed do not mention the need to share research data and when it is mentioned, this obligation is addressed to research and knowledge dissemination bodies (España, 2013a; España, 2013b; España, 2015). In addition, these texts refer to the Law of science, technology and innovation (España, 2011), which in the section "Dissemination in open access", indicates that public agents of the Spanish System of Science, Technology and Innovation (Sistema Español de Ciencia, Tecnología e In- novación) should promote the development of open access repositories that combine the publications of their research staff.

\subsubsection{Indirect aid}

Neither the State nor the European texts that regulate indirect aid contain specific obligations of active publicity. That is, companies that benefit from indirect incentives do not have to carry out any communication activity.

\section{Should we expand communication ac- tions?}

\section{Conclusions}

The analysis performed allows us to draw the following conclusions:

- The regulations that normalise direct R\&D\&I aid are more numerous and concrete than the regulations that normalise indirect aid. It could be of interest to homogenise the scope of these and also the provisions related to communication requirements.

- All the texts include a mention of the need to carry out activities that contribute to the public in general and the academic community being informed of the R\&D projects that are subsidised. This is aligned with the guidelines of the Spanish Science, Technology and Innovation System (Sistema Español de Ciencia, Tecnología e Innovación) and with the communication, transparency and data sharing priorities indicated by the EU.

- Regarding communication requirements, different terms are used in European and State regulations. The first one mentions advertising, information and communication and the second one only advertising. Therefore, it would be of interest to homogenise the designation used.

- Both European and Spanish regulations establish the minimum activities to be undertaken, although they do not exactly coincide. We should consider whether these activities should match and be broadened, as currently these basically consist of the insertion of the logos and emblems of the managing agencies into the generated materials, the inclusion of a reference on the web or displaying informative posters when certain amounts are exceeded. It could also be assessed whether the requirements should be different depending on the type of aid (loan, subsidy, tax incentive...), the amount of the project or the type of project (research, development and innovation). Concerning transparency needs, the data that should be published is completely clear.

- The content of the communication activities is not detailed in all of the texts. European regulations indicate that the beneficiary company must include a web reference in which the objectives and results are described (European Union, 2013). This should also be considered in Spanish texts. In addition, in both cases, it would be useful to detail which sections should be published and how, in order to improve the quality of the information and its visibility and accessibility, which is often disperse (Cruz-Rubio, 
2017) or not available (Beltrán-Orenes; Martínez-Pastor, 2017).

- The proportionality of communication activities is not taken into account in all documents. European regulations clarify that a web reference proportional to the support received must be included (European Union, 2013). It would be better if it defined this proportionality. In the case of Spanish legal texts, it would be interesting to include this aspect.

- The responsibilities are clear in all cases and fall on the managing authorities and beneficiaries. Perhaps the managing bodies could develop more activities for the benefit of communication and transparency, in addition to submitting information on concession resolutions to the National grants database (Base de datos nacional de subvenciones, BDNS).

- The cases of non-compliance are only included in the state regulations. In some cases, it is included as explicit mention and others in more general terms. Its homogenisation could be an improvement.

- Open access is a general principle, both for the EU and for Spain, and is included in the legal system that regulates R\&D aid. However, it is mainly aimed at making the research carried out by public agents (universities, research centres, etc.) visible. Therefore, it could include measures that reward open access in private companies, that help make their research visible and that optimise public resources (Torres-Salinas; Robinson-García; Cabezas-Clavijo, 2012). This issue requires an in-depth analysis to determine: what measures can be requested without harming confidentiality, in what term they should do so and what kind of benefit can be offered for doing so.

- In accordance with the previous point, it would be interesting to expand the information contained in the BDNS referring to the companies that have obtained aid. This would be an advancement, without compromising confidentiality, and would include the title of the subsidised project and a brief description (proportional to the assistance received). Another useful option, which might complement or replace the previous one, would be the creation of a database similar to OpenAIRE or Recolecta, but focused on $\mathrm{R}+\mathrm{D}+\mathrm{I}$ projects executed by companies. CDTI or Mineco could play a prominent role in its implementation.

- There is a very significant difference between direct and indirect aid. In the latter, no mention is made of communication, transparency or data sharing, neither in the state nor in the European regulations. A practical first step would be to include the companies that are benefiting from these incentives in the BDNS.

Data sharing should be encouraged in companies

\section{Bibliography}

Beltrán-Orenes, Pilar; Martínez-Pastor, Esther (2016). “Grado de cumplimiento de las leyes de transparencia, acceso y buen gobierno y de reutilización de los datos de contratación de la administración central española". El profesional de la información, v. 25, n. 4, pp. 557-567.

http://dx.doi.org/10.3145/epi.2016.jul.05

Beltrán-Orenes, Pilar; Martínez-Pastor, Esther (2017). “Organización de la información y sujetos obligados en el Portal de la transparencia de España". El profesional de la información, v. 26, n. 5, pp. 983-994.

https://doi.org/10.3145/epi.2017.sep.19

Cruz-Rubio, César-Nicandro (2017). "Ley de transparencia y grandes empresas en España”. Madrid: Transparency International España. ISBN: 9788469743089

España (2003a). “Ley 38/2003, de 17 de noviembre, General de subvenciones". BOE, n. 276, 18 noviembre.

https://www.boe.es/buscar/act.php?id=BOE-A-2003-20977

España (2003b). "Real decreto 1432/2003, de 21 de noviembre, por el que se regula la emisión por el Ministerio de Ciencia y Tecnología de informes motivados relativos al cumplimiento de requisitos científicos y tecnológicos, a efectos de la aplicación e interpretación de deducciones fiscales por actividades de investigación y desarrollo e innovación tecnológica". BOE, n. 286, 29 noviembre.

https://www.boe.es/diario_boe/txt.php?id=BOE-A-2003-21847

España (2006). “Real decreto 887/2006, de 21 de julio, por el que se aprueba el Reglamento de la Ley 38/2003, de 17 de noviembre, General de subvenciones". BOE, n. 176, 25 julio.

https://www.boe.es/diario_boe/txt.php?id=BOE-A-2006-13371

España (2011). “Ley 14/2011, de 1 de junio, de la Ciencia, la tecnología y la innovación". BOE, n. 131, 2 junio.

https://www.boe.es/buscar/act.php?id=BOE-A-2011-9617

España (2013a). “Orden ECC/1402/2013, de 22 de julio, por la que se aprueban las bases reguladoras para la concesión de ayudas en el marco del Programa estatal de promoción del talento y su empleabilidad, del Plan estatal de investigación científica y técnica y de innovación 2013-2016". BOE, n. 176, 22 julio.

https://www.boe.es/diario_boe/txt.php?id=BOE-A-2013-8080

España (2013b). “Orden ECC/1780/2013, de 30 de septiembre, por la que se aprueban las bases reguladoras para la concesión de ayudas públicas del Programa estatal de investigación, desarrollo e innovación orientada a los retos de la sociedad, en el marco del Plan estatal de investigación científica y técnica y de innovación 2013-2016". BOE, n. 236, 2 octubre.

https://www.boe.es/boe/dias/2013/10/02/pdfs/BOE-A-2013-10259. $p d f$

España (2013c). "Ley 19/2013, de 9 de diciembre, de transparencia, acceso a la información pública y buen gobierno". $B O E$, n. 295, 10 diciembre.

https://www.boe.es/buscar/doc.php?id=BOE-A-2013-12887

España (2014a). "Real decreto 475/2014, de 13 de junio, sobre bonificaciones en la cotización a la Seguridad Social del personal investigador". BOE, n. 144, 14 junio.

https://www.boe.es/diario_boe/txt.php?id=BOE-A-2014-6276 
España (2014b). “Ley 15/2014, de 16 de septiembre, de racionalización del Sector público y otras medidas de reforma administrativa". BOE, n. 226, 17 septiembre.

https://www.boe.es/diario_boe/txt.php?id=BOE-A-2014-9467

España (2014c). "Ley 27/2014, de 27 de noviembre, del Impuesto sobre sociedades". BOE, n. 288, 28 noviembre.

https://www.boe.es/buscar/act.php?id=BOE-A-2014-12328

España (2015). “Orden ECC/1333/2015, de 2 de julio, por la que se aprueban las bases reguladoras para la concesión de ayudas públicas del Programa Estatal de Liderazgo Empresarial en I+D+I, en el marco del Plan Estatal de Investigación Científica y Técnica y de Innovación 2013-2016". BOE, n. 159, 4 julio.

https://www.boe.es/diario_boe/txt.php?id=BOE-A-2015-7484

European Commission (2014). "Framework for state aid for research and development and innovation". (2014/C 198/01). Official Journal of the European Union, June, $27^{\text {th }}$. https://goo.gl/8myhd7

European Union (2013). “Regulation n. 1303/2013 of the European Parliament and of the Council of 17 December 2013 laying down common provisions for the European Regional Development Fund, the European Social Fund, the Cohesion Fund, the European Agricultural Fund for Rural Development and the European Maritime and Fisheries Fund, and laying down general provisions concerning the European Regional Development Fund, the European Social Fund, the Cohesion Fund and the European Maritime and Fisheries Fund, and repealing the Regulation (EC) no. 1083/2006 of the Council." Official Journal of the European Union.

https://goo.gl/bfnQGQ

European Union (2014). “Regulation (EU) No 821/2014 of 28 July 2014 laying down rules for the application of Regulation (EU) No 1303/2013 of the European Parliament and of the Council as regards detailed arrangements for the transfer and management of programme contributions, the reporting on financial instruments, technical characteristics of information and communication measures for operations and the system to record and store data." Official Journal of the European Union.

https://goo.gl/tQ9s4M

González, Xulia; Jaumandreu, Jordi; Pazó, Consuelo (2005). "Barriers to innovation and subsidy effectiveness". RAND
Journal of economics, v. 36, n. 4, pp. 930-950.

http://www.jstor.org/stable/4135264

Hernández-Pérez, Tony; García-Moreno, María-Antonia (2013). "Datos abiertos y repositorios de datos: nuevo reto para los bibliotecarios". El profesional de la información, v. 22, n. 3, pp. 259-263.

http://dx.doi.org/10.3145/epi.2013.may.10

Ministerio de Economía y Competitividad (Mineco) (2013). Plan estatal de investigación científica, técnica y de innovación. Madrid: Ministerio de Economía y Competitividad. https://goo.gl/M9tYh4

Ministerio de Hacienda y Administraciones Públicas (Minhap) (2017). Presentación del proyecto de Presupuestos generales del Estado 2017.

https://goo.gl/U27E3M

Moreno-Sardà, Amparo; Molina-Rodríguez-Navas, Pedro; Simelio-Solà, Núria (2017). "Impacto de la legislación sobre transparencia en la información publicada por las administraciones locales". El profesional de la información, v. 26, n. 3, pp. 370-380.

https://doi.org/10.3145/epi.2017.may.03

OECD (2007). OECD Principles and guidelines for access to research data from public funding. ISBN: 9789264034020 https://goo.gl/wZnYv3

http://dx.doi.org/10.1787/9789264034020-en-fr

Pacios, Ana-Reyes; Vianello-Osti, Marina; Rodríguez-Bravo, Blanca (2016). "Transparency and access to information on research projects in Spanish public universities". El profesional de la información, v. 25, n. 5, pp. 721-729. https://doi.org/10.3145/epi.2016.sep.02

Sanhueza, Paulina; Rodríguez, Ignacio; Padilla, Patricio (2012). "Difusión y acceso a datos e información científica y tecnológica en la normativa de fondos públicos para la innovación en Chile". J. Technol. Mang. Innov, v. 7, n. 4, pp. 148-163.

http://dx.doi.org/10.4067/S0718-27242012000400012

Torres-Salinas, Daniel; Robinson-García, Nicolás; Cabezas-Clavijo, Álvaro (2012). "Compartir los datos de investigación en ciencia: introducción al data sharing". El profesional de la información, v. 21, n. 2, pp. 173-184.

http://dx.doi.org/10.3145/epi.2012.mar.08

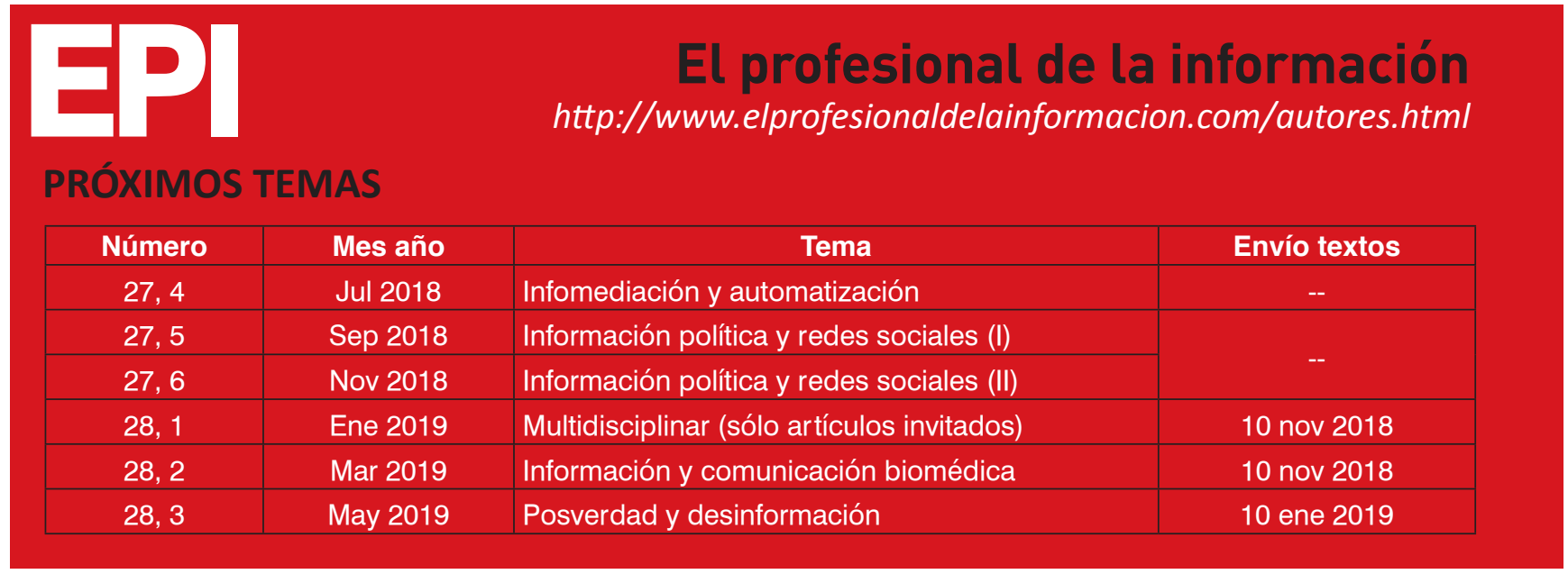




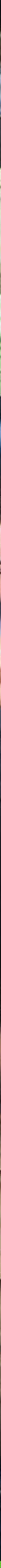

\section{0 años diseñando}

y gestionando información

MASmedios apoya la Declaracion de Lyon del 2014 que

propugna el derecho de las personas a acceder a la información.

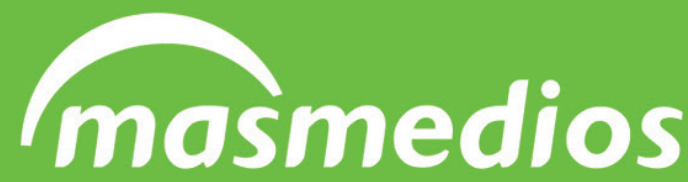

www.masmedios.com 